\title{
Hospital length of stay for severe COVID-19 patients: implications for Remdesivir's value
} Michaela R Anderson MD MS ${ }^{1}$,

\author{
Peter B. Bach MD MAPP2², Matthew R. Baldwin MD MS ${ }^{1^{*}}$
}

* Indicates that these authors contributed equally to this work

${ }^{1}$ Department of Medicine, Division of Pulmonary, Allergy, and Critical Care, Columbia University Irving Medical Center, New York, NY

${ }^{2}$ Center for Health Policy and Outcomes, Memorial Sloan Kettering Cancer Center, New York, NY

\section{Corresponding Authors:}

Peter B Bach, Director, Center for Health Policy and Outcomes, Memorial Sloan Kettering Cancer Center 1275 York Avenue, NYC, NY 10065

Email: bachp@maskcc.org

Matthew R Baldwin, Assistant Professor, Columbia University Irving Medical Center 622 West $168^{\text {th }}$ Street, PH8E-101, NYC, NY 10032

Email:mrb45@cumc.columbia.edu

Word Count: 621

References: 6 
medRxiv preprint doi: https://doi.org/10.1101/2020.08.10.20171637; this version posted August 12, 2020. The copyright holder for this preprint (which was not certified by peer review) is the author/funder, who has granted medRxiv a license to display the preprint in perpetuity. All rights reserved. No reuse allowed without permission.

In June 2020 Gilead Sciences CEO announced that US hospitals would be charged $\$ 3,120$ for a course of remdesivir, a price roughly 33\% higher than the company plans to charge other high-income countries. ${ }^{1}$ The sole justification offered was that remdesivir would save hospitals $\$ 12,000$ per patient by shortening hospital length of stay (LOS) by four days. This presumed benefit was extrapolated from the ACTT-1 trial, which found median time to recovery (an approximation of median time to hospital discharge) of 11 days in patients receiving remdesivir versus 15 days in those receiving placebo. ${ }^{2}$

But as justification for such a high price it is critical that the ACTT-1 finding is robust. It may not be, either because the outcomes of the study population are not generalizable, or because of exclusion from the trial of patients who were expected to be discharged within 72 hours. Remdesivir treatment requires a 5-day inpatient stay, so patients who would otherwise be discharged sooner may remain hospitalized to complete treatment. This also limits the achievable LOS reduction for patients who would otherwise be hospitalized 5-8 days. The remdesivir Emergency Use Authorization does not limit its use based on LOS, and specifies that intravenous remdesivir be given in an in-patient setting. ${ }^{3}$ We assessed what percentage of severe COVID-19 patients belonged to each of these LOS groups in a real world cohort.

\section{Methods}

Our study cohort consisted of adults age $\geq 18$ years with severe COVID-19 consecutively hospitalized from the emergency department (ED) at NewYork-Presbyterian Columbia University Medical Center and the Allen community hospital between March 9, 2020 and April 23, 2020, with follow-up through June 10, 2020. Data abstraction methods have been published previously. ${ }^{4}$ We defined severe COVID-19 based on remdesivir trial and FDA criteria: an initial oxygen saturation $\leq 94 \%$ on room air or the use of any supplemental oxygen within 24 hours of ED presentation. ${ }^{2,5}$ LOS was measured from presentation to death or hospital discharge.

\section{Results}

There were 1,643 adults admitted with severe COVID-19, after excluding 21 (1\%) who were discharged in $<9$ days to another hospital. The median age was 67 (interquartile range, 56-78) years, a majority were Hispanic or Black and had $\geq 1$ comorbidity, $12 \%$ required mechanical ventilation within 24 hours, median LOS was 7 (3-14) days, and in-hospital 28-day 
mortality was $26 \%$. Five-hundred and eighty-six patients (36\%) had a LOS of 1-4 days, 384 (23\%) had a LOS of 5-8 days, and 673 (41\%) were hospitalized $\geq 9$ days (Table). The distribution was similar when excluding patients who died during their hospital stay (Table). The majority of those with a LOS of $1-4$ or $5-8$ days were $\geq 60$ years old $(67 \%$ and $70 \%$, respectively, Figure).

\section{Discussion}

In our cohort the median LOS was markedly shorter than the equivalent endpoint in the ACTT-1 trial ( 7 days vs. 15 days). This difference raises immediate questions as to whether remdesivir could reduce LOS by the four days used to justify the treatment's price. We found that only $41 \%$ of patients could both receive a 5 -day course of remdesivir and have LOS shortened by 4 days or more, while $36 \%$ could have their LOS potentially prolonged to complete therapy.

Our evaluation is relevant to the extent that our older-adult multi-morbidity predominant cohort is representative of severe COVID-19; LOS may be even shorter in younger and healthier populations. Our data are from patients hospitalized before dexamethasone became standard of care. Some patients may be prescribed 10 rather than 5 days of remdesivir, which could further prolong LOS (both durations are authorized by the FDA). Whether physicians will keep patients who otherwise could be discharged to complete treatment could not be determined.

Studying shorter remdesivir treatment courses, developing intranasal remdesivir, ${ }^{6}$ and implementing programs to facilitate outpatient intravenous remdesivir administration should be considered. 
medRxiv preprint doi: https://doi.org/10.1101/2020.08.10.20171637; this version posted August 12, 2020. The copyright holder for this preprint (which was not certified by peer review) is the author/funder, who has granted medRxiv a license to display the preprint in perpetuity. All rights reserved. No reuse allowed without permission.

\section{Acknowledgments}

\section{Author Contributions:}

Drs Anderson and Baldwin had full access to all of the data in the study and take responsibility for the integrity of the data and the accuracy of the data analysis. Study concept and design: Anderson, Bach, Baldwin. Acquisition, analysis, and interpretation of data: Anderson, Baldwin. Drafting of the manuscript: Anderson, Bach, Baldwin. Critical revision of the manuscript for important intellectual content: Anderson, Bach, Baldwin. Statistical analysis: Anderson, Baldwin.

\section{Funding/Support}

This study was supported in part by NIH UL1 TR001873 and the Parker B Francis Foundation. None of the listed funding sources were involved in the design or conduct of this study, the collection, management, analysis or interpretation of data, the preparation, review or approval or this manuscript, or the decision to submit this manuscript for publication.

\section{Financial Disclosures}

Dr. Baldwin served as site co-investigator for Gilead Sciences Remdesivir trials GS-US-5405774 and GS-US-540-5773 and received no funding. Dr. Bach reports personal fees and nonfinancial support from American Society for Health-System Pharmacists, personal fees from WebMD, personal fees from Defined Health, personal fees from JMP Securities, personal fees from Mercer, personal fees and non-financial support from United Rheumatology, personal fees from Foundation Medicine, personal fees from Grail, personal fees from Morgan Stanley, personal fees from NYS Rheumatology Society, personal fees and non-financial support from Oppenheimer \& Co, personal fees from Cello Health, personal fees, non-financial support and other from Oncology Analytics, personal fees from Anthem, personal fees from Magellan Health, personal fees and non-financial support from Kaiser Permanente Institute for Health Policy , personal fees and non-financial support from Congressional Budget Office, personal fees and non-financial support from America's Health Insurance Plans, grants from Kaiser Permanente, grants from Arnold Ventures, personal fees and non-financial support from Geisinger, personal fees from EQRx, personal fees from Meyer Cancer Center of Weill Cornell Medicine, personal fees from National Pharmaceutical Council, outside the submitted work. 
medRxiv preprint doi: https://doi.org/10.1101/2020.08.10.20171637; this version posted August 12, 2020. The copyright holder for this preprint (which was not certified by peer review) is the author/funder, who has granted medRxiv a license to display the preprint in perpetuity.

All rights reserved. No reuse allowed without permission.

\section{$\underline{\text { References }}$}

1. An Open Letter from Daniel O'Day, Chairman and CEO, Gilead Sciences [press release]. Forst City, California: Business Wirie, June 29, 20202020.

2. Beigel JH, Tomashek KM, Dodd LE, et al. Remdesivir for the Treatment of Covid-19 Preliminary Report. N Engl J Med. 2020.

3. Coronavirus (COVID-19) Update: FDA Issues Emergency Use Authorization for Potential COVID-19 Treatment. https://www.fda.gov/news-events/pressannouncements/coronavirus-covid-19-update-fda-issues-emergency-use-authorizationpotential-covid-19-treatment. Accessed July 20, 2020.

4. Geleris J, Sun Y, Platt J, et al. Observational Study of Hydroxychloroquine in Hospitalized Patients with Covid-19. N Engl J Med. 2020;382(25):2411-2418.

5. Goldman JD, Lye DCB, Hui DS, et al. Remdesivir for 5 or 10 Days in Patients with Severe Covid-19. N Engl J Med. 2020.

6. Gilead to begin human trials for the inhaled version of coronavirus drug remdesivir. https://www.cnbc.com/2020/06/22/coronavirus-drug-gilead-to-begin-trials-for-theinhaled-version-of-remdesivir.html. Accessed July 20, 2020. 
medRxiv preprint doi: https://doi.org/10.1101/2020.08.10.20171637; this version posted August 12, 2020. The copyright holder for this preprint (which was not certified by peer review) is the author/funder, who has granted medRxiv a license to display the preprint in perpetuity.

All rights reserved. No reuse allowed without permission.

\section{FIGURE LEGENDS}

Figure: Frequency histogram by age groups for hospital length of stay among severe COVID-19 patients with hospital length of stay of $1-4$ days $(n=586,36 \%), 5-8$ days $(n=384,23 \%), \geq 9$ days $(n=673,41 \%)$. 
Table: Baseline characteristics by hospital length of stay

\begin{tabular}{|c|c|c|c|c|}
\hline & $\begin{array}{l}\text { Length of } \\
\text { stay } 1-4 \\
\text { days } \\
(n=586)\end{array}$ & $\begin{array}{c}\text { Length of } \\
\text { stay 5-8 } \\
\text { days } \\
(n=384)\end{array}$ & $\begin{array}{c}\text { Length of } \\
\text { stay } \geq 9 \\
\text { days } \\
(n=673)\end{array}$ & $p$ value \\
\hline Median age, years (IQR) & $68(55-80)$ & $68(57-79)$ & $67(56-75)$ & 0.03 \\
\hline Sex, male & $325(55)$ & $212(55)$ & $424(63)$ & \\
\hline Race/Ethnicity & & & & 0.67 \\
\hline White Non-Hispanic & $44(8)$ & $33(9)$ & $63(9)$ & \\
\hline Black Non-Hispanic & $60(10)$ & $41(11)$ & $78(12)$ & \\
\hline Hispanic & $318(54)$ & $198(52)$ & $329(49)$ & \\
\hline Other & $83(14)$ & $65(17)$ & $104(15)$ & \\
\hline Declined & $81(14)$ & $47(12)$ & $99(15)$ & \\
\hline \multicolumn{5}{|l|}{ Comorbidities } \\
\hline Asthma/COPD & $84(14)$ & $70(18)$ & $125(19)$ & 0.10 \\
\hline Hypertension & $297(51)$ & $194(51)$ & $339(50)$ & 0.99 \\
\hline Chronic kidney disease & $79(13)$ & $79(21)$ & $123(18)$ & 0.009 \\
\hline Cancer & $53(9)$ & $42(11)$ & $102(15)$ & 0.003 \\
\hline Smoking & $42(17)$ & $52(14)$ & $83(12)$ & 0.002 \\
\hline Diabetes & $209(36)$ & $153(42)$ & $280(42)$ & 0.045 \\
\hline Pulmonary Heart Disease & $33(6)$ & $24(6)$ & $45(7)$ & 0.74 \\
\hline Median number of comorbidities (IC & $1(0-2)$ & $1(0-3)$ & $1(0-3)$ & 0.005 \\
\hline Participation in Remdesivir trial ${ }^{*}$ & $7(1)$ & $3(1)$ & $35(5)$ & $<0.001$ \\
\hline Discharge Disposition & & & & $<0.001$ \\
\hline Home & $356(61)$ & $238(62)$ & $219(33)$ & \\
\hline Rehabilitation Center & $35(6)$ & $47(12)$ & $190(28)$ & \\
\hline Death & $168(29)$ & $81(21)$ & $173(26)$ & \\
\hline Hospice & $27(5)$ & $18(5)$ & $30(4)$ & \\
\hline Transferred to other hospital & $0(0)$ & $0(0)$ & $8(1)$ & \\
\hline Hospitalized at study completion & $0(0)$ & $0(0)$ & $53(8)$ & \\
\hline
\end{tabular}

Definition of abbreviations: COPD: chronic obstructive pulmonary disease; IQR: interquartile range. Values presented as $\mathrm{n}(\%) . P$ values calculated using Kruskal-Wallis tests or Chi-square tests.

${ }^{*}$ Gilead GS-US-540-5774 or GS-US-540-5773. 
medRxiv preprint doi: https://doi.org/10.1101/2020.08.10.20171637; this version posted August 12, 2020. The copyright holder for this preprint (which was not certified by peer review) is the author/funder, who has granted medRxiv a license to display the preprint in perpetuity.

All rights reserved. No reuse allowed without permission.

Figure: Frequency histogram by age groups for hospital length of stay among severe COVID-19 patients with hospital length of stay of $1-4$ days $(n=586,36 \%), 5-8$ days $(n=384,23 \%), \geq 9$ days $(n=673,41 \%)$.

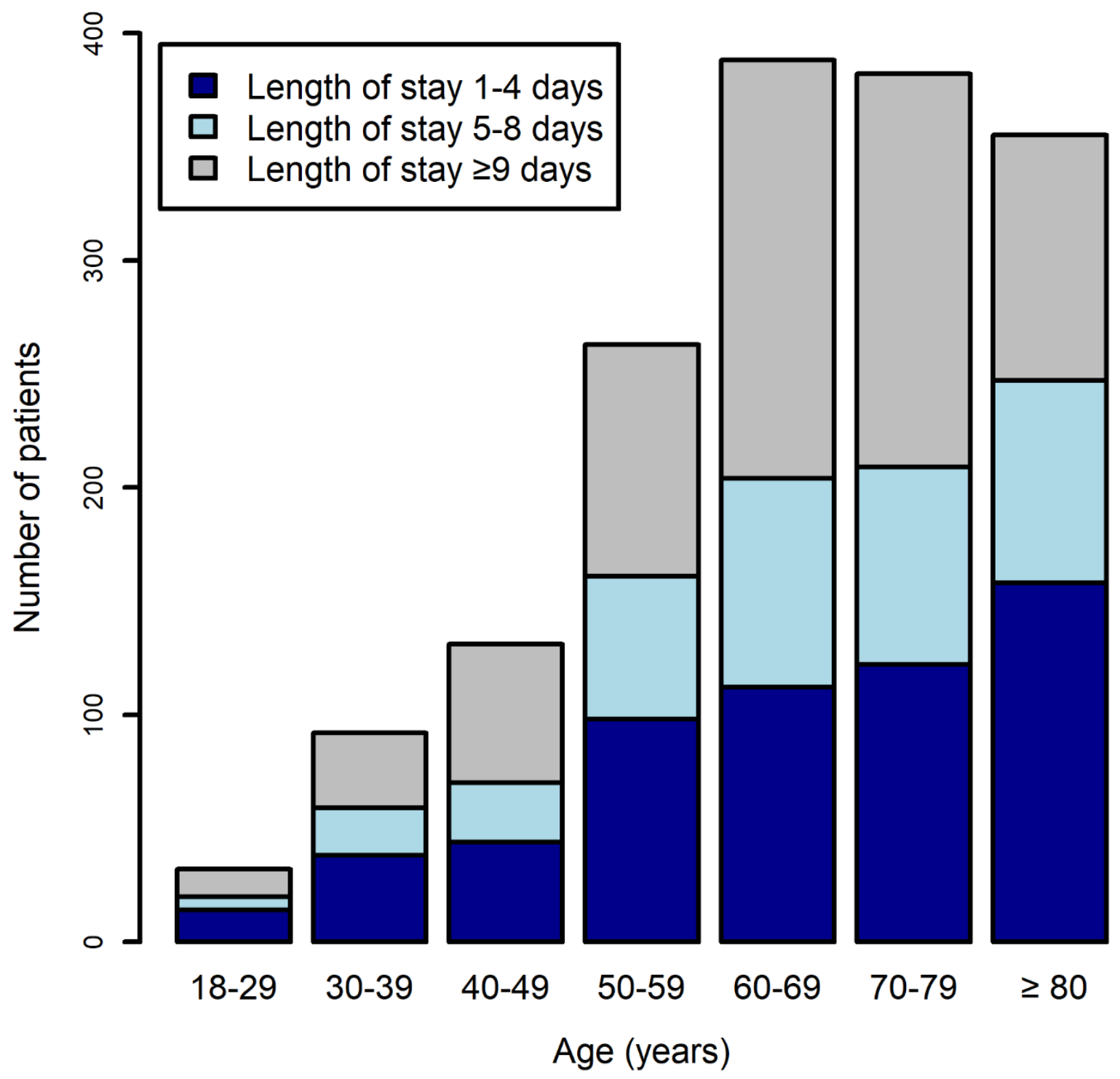

